AperTO - Archivio Istituzionale Open Access dell'Università di Torino

\title{
English as a Bridge: An L3-Approach to Contrastive Linguistics
}

\section{This is a pre print version of the following article:}

Original Citation:

Availability:

This version is available http://hdl.handle.net/2318/1724017 since 2020-01-20T13:38:24Z

Publisher:

Bloomsbury Academic

Terms of use:

Open Access

Anyone can freely access the full text of works made available as "Open Access". Works made available under a Creative Commons license can be used according to the terms and conditions of said license. Use of all other works requires consent of the right holder (author or publisher) if not exempted from copyright protection by the applicable law. 


\title{
English as a bridge: An L3-approach to contrastive linguistics ${ }^{1}$
}

\author{
Livio Gaeta
}

Contrastive Analysis has to be understood as a micro-typology able to attain a degree of granularity which is far beyond any macro-typological research. In this regard, given its role as 'global language', English will be fruitful for the purposes of Contrastive Analysis and its didactic implications insofar as it will serve as a bridge language for a micro-typology in which it is systematically contrasted trilaterally with Italian and German. In particular, the chapter will focus on two case studies taken respectively from the temporal-aspectual domain, and the morphosyntax of subjects and objects.

\section{Introduction}

As is well known, Contrastive Linguistics saw the light as an empirical hypothesis on language acquisition when first Charles Fries, and subsequently Robert Lado, suggested to incorporate the tradition of comparative studies into the discussion for foreign language teaching as the latter emerged in the golden age of Structuralism, with a particular focus on phonological studies. The so-called Contrastive Analysis Hypothesis basically maintains that 'in the comparison between native and foreign language lies the key to ease our difficulty in foreign language learning' (Lado 1957). To find this key, we have to make use of 'effective materials ... based upon a scientific description of the language to be learned, carefully compared with a parallel description of the native language of the learner' (Fries 1945). In spite of several attempts to apply this suggestive hypothesis to the method and practice of language teaching, especially in the 1960s and the 1970s, the results were rather scarce, which ultimately led to abandoning this enterprise as a general framework apt for developing methods for language teaching.

Its limits must probably be sought in its scarce degree of elaboration as a language acquisition theory. In particular, it has been objected (cf. Gast 2011, 2013; König 2012a, b) that in order to be taken seriously as an acquisition theory, Contrastive Analysis should essentially be improved with regard to its capacity for differentiating acquisition stages, as well as taking into account important parameters in the acquisition of 
a second language, such as, for instance, natural (L2) versus mediated acquisition head is fine.

(Foreign Language), sequential or simultaneous acquisition, L2- versus L3-acquisition, etc. (cf. Carrol and Lambert 2006; von Stutterheim and Lambert 2005; Hawkins and Filipović 2011). Furthermore, Contrastive Analysis lacks a solid psychological base providing a general framework suitable for language acquisition, and - from a more practical point of view - it never developed a reliable empirical base which might have supplied a sufficient theoretical elaboration. Finally, since it cannot seriously be credited as a language acquisition theory, Contrastive Analysis turns out to lack a clear epistemological status with regard to other comparative approaches developed in linguistics, and, in the first place, the typological and the historical-comparative school.

\section{The typological turn}

Recently, the attempt has been made to overcome the deadlock hinted at in the previous section by taking seriously the idea that Contrastive Analysis represents an extreme case of typological comparison carried out on the basis of a small language sample (cf. König 1996). ${ }^{2}$ One main advantage of a typological comparison conceived in these terms consists in the high granularity of the structural analysis which has become elusive, especially in recent typological investigations based on very large language samples. Considered from this vantage point, Contrastive Analysis aims to identify structural correlations of a typological nature and - besides attaining explanations of a general order with regard to language structure - has as ultimate goal to 'unify the contrasts' (Hawkins 1986). In this way, Contrastive Analysis can be understood as a 'pilot typology' (van der Auwera 2012; Gaeta 2014) or as a 'micro-typology', and constitutes an autonomous object of investigation which is interesting in itself, independent of any didactic finality and/or application.

In order to carry out this research programme, it is convenient to limit the 'microtypological' comparison to a small number of languages, generally two, at most, three or four. In the light of the small sample, the comparison is expected to consider highly complex structural aspects involving a high number of linguistic traits with the explicit aim of attaining a granularity which is far beyond any macro-typological research. At any rate, in compliance with this latter goal, the issue of comparability has clearly to be the compass orienting the empirical research. Concretely, this consists of the identification of similarities and differences of two or more language-specific categories along a certain dimension, as, for instance, exemplified by Haspelmath's (2010) definition of what a future tense has to be composed of: 'A future tense is a grammatical marker associated with the verb that has future time reference as one prominent meaning.' In other words, a central tenet of Contrastive Analysis is the comparative method exploiting an onomasiological approach to the Ontological Domain, for example, (future) time reference.

On the other hand, in the light of the quite complex functional space which can be occupied by a morpheme or - in more precise terms - by a grammatical construction, the onomasiological approach has to be combined with a semasiological approach depicting the range of Ontological Categories conveyed 


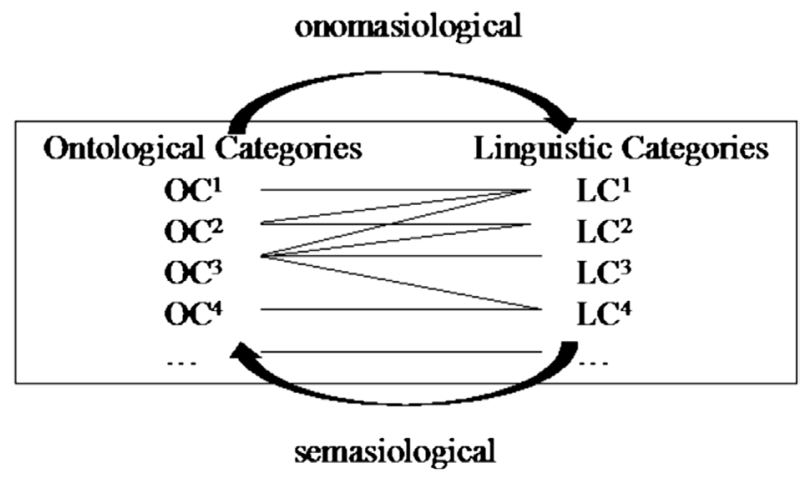

Figure 2.1 Comparative method in Contrastive Analysis.

by or associated with a Linguistic Expression. Although formal and functional properties often stand in manifold relationships as shown in Figure 2.1 above, their relation is not entirely arbitrary and can be represented with the help of semantic maps (cf. van der Auwera 2012).

Moreover, the languages undergoing Contrastive Analysis are likely to have a connection of a socio-cultural type (cf. Gast 2011, 2013). This is given by a significant number of bilingual or multilingual speakers and/or a significant quantity of linguistic performances (texts, discourses, etc.) translated by a language into the other(s) which testify to relations of cultural exchange or contact. The latter are expected hopefully to be structured in (especially parallel) translation and/or learners' corpora. Such a requirement enhances the role of contact phenomena and especially of areality for the contrastive perspective. This has been shown by recent typological enterprises to be one of the main factors shared by most languages in Europe, as witnessed by the debate around Wharf's old idea of a Standard Average European (SAE) and the so-called Charlemagne-Sprachbund consisting of one or more centres surrounded by several possible peripheries (cf. Ramat 1998; Haspelmath 2001). In this way, single linguistic aspects traditionally considered in a separate manner can be shown to be crucially conjoined by areal features. For instance, one can mention the so-called 'Germanic sandwich' consisting of Dutch contrasted with English and German and clearly influenced by contact with Romance languages to a different extent with regard to its cognate languages (Hüning, Vogl and van der Wouden 2006).

\section{English as a bridge language}

Comprehended in the wider perspective sketched above in which the SAE is a fundamental vantage point, one can attempt a further challenge involving English in its role of 'global language' (cf. Crystal 2003). In this regard, although more and more speakers master or have access to it - often as a first foreign language - the advantage in didactic terms of the 'global' status reached by English in the last decades has not been seriously exploited yet. ${ }^{3}$ This is even more surprising in the light of several 
contrastive investigations available, for instance, for English and Italian (cf. Iamartino 2001; Vanni 2016), or for Italian and German (cf. Blasco Ferrer 1999; Bosco Coletsos and Costa 2013; Di Meola and Puato 2015), and especially for English and German (cf. Kufner 1962; Moulton 1962; Hawkins 1986; König and Gast 2007). For the latter two languages, the 'micro-typological comparison' is highly significant also from a historical-comparative point of view insofar as their contrasts have to be regarded as the result of a long-standing diachronic development: 'Where the grammars of English and German contrast, the surface forms (morphological and syntactic) of German are in closer correspondence with their associated meanings' (Hawkins 1986: 121).

In addition, at least with respect to the other European languages and in the first place, Italian, English and German form an essential part of the SAE, although their position is more or less peripheral, displaying more or less strict contacts with and influences of Romance or Celtic languages.

In the next sections, I will try to further develop this idea of taking English as a bridge language for a micro-typology in which it is systematically contrasted with Italian and German. In particular, I will focus on two case studies of such a trilateral Contrastive Analysis with regard to the temporal-aspectual domain and to the morphosyntactic properties of subjects and objects. These subjects have been conveniently chosen because of their well-defined Onomasiological and/or Semasiological Domain, which allows us to carve out sets of data which are easily matched within a highly granular trilateral comparison.

\subsection{The temporal-aspectual domain}

The onomasiological background of future time reference has been already sketched in Section 2. The definition has to be further articulated with regard to the reliability of the prediction entailed in the future time reference. Accordingly, the onomasiological space is carved out in English in the following way (see König and Gast 2007: 84-7 for details).

The reliability of the prediction clearly plays a crucial role in German, as well as in Italian, future time reference, although the picture is essentially less articulated than in English:

Both in German and in Italian the forms used to convey present tense, respectively the Präsens and the presente, are also commonly used for future time reference; in this way, a more reliable prediction is intended by the speaker with respect to what is normally obtained by using the future tense forms, namely the Futur I and the futuro. This is shown especially by the contrast between their usage in the same context (see Table 2.2, Examples 1ii vs 2ii for German, and Examples 3ii and 4ii for Italian). On the other hand, when the future time reference is profiled as imminent, either the future tense is inappropriate because the prediction is highly reliable (see Table 2.2, Example 4ii) or vice versa: the present tense is odd because it is rather about a supposition (see Table 2.2, Example 4iii). It should be stressed that this difference is independent of the time adverbial employed in the sentence. In addition, in Italian, a specific form for the imminential future occurs which stands in competition with the present tense, while the future tense is odd (see Table 2.2, Example 3iii). On the other hand, the present 
Table 2.1 The Onomasiological Space of English Future Time Reference

1) Complete reliability / Imminential future + reliable

a) be going to + infinitive

i) It's going to rain.

ii) Are you going to play tennis today?

2) Contingent reliability (also in connection with a condition)

\section{a) future}

i) Tomorrow's weather will be cold and cloudy.

ii) We'll miss the train if we don't hurry up.

3) Event scheduled by a program

a) present

i) Mary starts her new job on Tuesday.

ii) The train leaves at 5 o'clock.

4) Reliability related to implicatures

\section{a) present progressive}

i) Are you playing tennis today?

ii) I'm taking Mary to the theatre tonight.

5) Reliability restricted (by external conditions)

\section{a) future progressive}

i) When will you be paying me back?

ii) You can come with me. I'll be driving through Soho anyway.

tense, the imminential future and a further periphrasis containing the verb andare 'to go', commonly used with a projective value, cannot be replaced by the progressive form which is also common in Italian (see Table 2.2, Examples 3iv-v).

English clearly contrasts with German and Italian with regard to the progressive form, because the latter has to be employed for present time reference with both activities and achievements ( $1 \mathrm{a}-\mathrm{b})$, while the present tense normally expresses a habitual or a scheduled event (1c) (see also Table 2.1, Example 3aii):

(1) a. Charlie is working / * works now.

b. Fred is starving $/{ }^{*}$ starves now.

c. Usually, Charlie works / ${ }^{*}$ is working three hours a day.

Italian is partially similar to English insofar as a grammaticalized progressive form can be used, which stands, however, as an alternative to the presente, although the latter can get a habitual interpretation in contrast to the former:

(2) a. Carlo sta lavorando / lavora ora.

'Charlie is working (lit. stands working) / works now' 
Table 2.2 The Onomasiological Space of German and Italian Future Time Reference

1) Präsens

i) Morgen beginnen die Vorlesungen.

'The lectures start tomorrow'.

ii) Im nächsten Jahr schließe ich mein Studium ab.

'Next year I will finish my studies.'

iii) Wenn wir uns nicht beeilen, kommen wir zu spät.

'If we don't hurry up, we'll be late.'

2) Futur I

i) Durch den Streik werden morgen viele Menschen zu spät zur Arbeit kommen.

'Because of the strike, many people will be late for work tomorrow.

ii) Im nächsten Jahr werde ich mein Studium abschließen.

'Next year I will finish my studies.'

iii) Eines Tages wirst du noch den Kopf verlieren.

'One day you will lose your mind again.'

+ reliable

te / stare per + infinitive

i) Domani iniziano le lezioni.

'The lectures start tomorrow'.

ii) Finisco gli studi l'anno prossimo.

'Next year I will end my studies.'

iii) Sta per piovere / Fra qualche minuto piove / ?pioverà. 'It's going to rain / In few minutes it will rain.'

iv) Stai per uscire / *uscendo stasera con Maria?

'Are you going out with Mary tonight?'

v) Giochi / Vai a giocare / ${ }^{\star S t a i ~ g i o c a n d o ~ a ~ t e n n i s ~ o g g i ? ~}$

'Are you going to play tennis today?'

4) futuro

i) Domani 'inizieranno le lezioni.

'The lectures start tomorrow.'

ii) Finirò gli studi l'anno prossimo.

'Next year I will finish my studies.'

iii) Domani per lo sciopero molti ?"arrivano / arriveranno

tardi al lavoro.

'Because of the strike, many people will be late for work tomorrow.'

b. Fred sta morendo / muore di fame ora.

'Fred is starving / starves now.'

In other words, a factor 'Pnin' forcing a strictly habitual interpretation of the present tense is at play in English as hinted at by Nabokov with his usual sense of humour: "I 
go now", said Hagen, who, though a lesser addict of the present tense than Pnin, also held it in favour' (Nabokov 1953/1989: 170).

In neat contrast with English and Italian - where it is robustly established - the progressive in German is rather to be conceived as an emergent category because it can be expressed by a number of constructions displaying a growing range of selectivity and/or a decreasing diffusion (cf. König and Gast 2007: 94):

(3) $\mathrm{V}+$ gerade $>$ sein $+a \mathrm{am} \mathrm{V}_{\mathrm{INF}}>$ sein + dabei $+\mathrm{V}_{\mathrm{INF}}>$ sein + beim $\mathrm{V}_{\mathrm{INF}}>$ sein $+\mathrm{im} \mathrm{V}_{\mathrm{INF}}$

a. Karl arbeitet gerade.

'Charlie is working.'

b. Karl ist am Arbeiten / Verhungern.

'Charlie is working / starving.'

c. Karl ist am Äpfelpflücken.

'Charlie is gathering apples.'

d. Als du kamst, war ich dabei, meinen Aufsatz abzuschließen / 'Äpfel zu essen. 'When you came in, I was closing my article / 'eating apples.'

e. Karl ist beim Arbeiten $/{ }^{*}$ Verhungern.

'Charlie is working / ${ }^{\star}$ starving.'

f. Karl ist im Kommen / *Arbeiten. 'Charlie is coming / *working.'

g. Karl ist arbeiten / einkaufen / schwimmen.

'Charlie is working / shopping / swimming (elsewhere).'

In this typical example of layering (cf. Hopper and Traugott 2003: 124), the commonest construction displays a lower degree of selectivity and a higher diffusion (3a), while the so-called rheinische Verlaufsform ('Rhenish progressive form', cf. DUDEN: 434) is diatopically restricted to western varieties (3b). The latter also allows for noun incorporation with unspecified objects (3c). The construction in (3d) preferably selects transitive verbs entailing a clear result state, while the constructions in (3e) and (3f) are limited respectively to agentive and movement verbs (cf. König and Gast 2007: 93). It has to be added that in German an absentive construction also occurs (3g) which - besides displaying a progressive value - also implies that the subject involved in the predication is not physically present in the speech situation (cf. de Groot 2000).

In agreement with the requirement discussed above relating to the occurrence of a significant number of translated texts in the languages involved in the Contrastive Analyses, in the following table, the results of research which looked at the correspondence of expressions with future time reference contained in a collection of German short stories in Italian and English translations are reported (cf. Gaeta 2006 for details):

As can be gathered from Table 2.3, the Präsens is mostly translated by means of the English future tense, while its present tense translation only amounts to onequarter of the total. This stands in neat contrast with Italian where both the presente and the futuro are used - although the presente slightly stands out - to which the two constructions containing the verbs stare 'to stand' and andare 'to go' must be added. On the other hand, the Futur I is mostly translated by means of the Italian futuro and 
Table 2.3 Italian and English Translation of German Future Reference

\begin{tabular}{|c|c|c|c|c|c|c|c|c|}
\hline$\%$ & $\%$ & & Italian & German & Englis & & $\%$ & $\%$ \\
\hline 24 & 47 & 38 & presente & & present & 9 & 24 & 11 \\
\hline 21 & 41 & 33 & futuro & Präsens & future & 28 & 74 & 35 \\
\hline 6 & 12 & 10 & $\begin{array}{l}\text { stare per }+\mathrm{INF} \\
\text { andare } a+\mathrm{INF}\end{array}$ & & be going to & 1 & 2 & 1 \\
\hline 1 & 4 & 2 & stare per + INF & & be going to & 11 & 28 & 14 \\
\hline 1 & 4 & 2 & presente & Futur I & & & & \\
\hline 31 & 92 & 49 & futuro & & future & 29 & 72 & 37 \\
\hline 16 & & 25 & & Others & & 1 & & 1 \\
\hline 100 & & 159 & & tot. & & 79 & & 100 \\
\hline
\end{tabular}

Source: Hermann, J. (1998), Sommerhaus, später (Frankfurt/M.: Fischer); Italian trans: (2001) Casa estiva, più tardi, trans. B. Griffini (Roma: edizioni e/o); English trans.: (2002) The Summer House, Later, trans. M. Bettauer Dembo (London: Flamingo).

of the English future tense, although in the latter language, a significant preference for the construction containing the verb go in one-third of the cases is observed. In short, the clear dominance of the correspondence of the English future for the future time reference found in the German original text emphasizes the role of the grammaticalized verb will used in the English construction. The latter has even been characterized as a 'grounding predication' insofar as it has the effect of anchoring a certain event to the 'ground' which consists in 'the speech event, its participants, and its immediate circumstances' (cf. Langacker 1991: 318). This results in a subjectification process in which the speaker's subjective perspective remains implicit, offstage, because it is wired into the conceptualization of the scene as a whole. The advanced status of subjectification of will is shown by its usage in predictions which are presented as universally valid laws, while in German and Italian respectively, the Präsens and the presente are strictly required:

(4) a. She will always drink her whiskey straight.

b. Sie trinkt.PRS ihr Whiskey pur / ?? wird ihr Whiskey pur trinken.FUT.

c. Lei beve.PRS / ??berrà.Fut sempre il suo whisky liscio.

On the other hand, the restricted usage of the Futur I with regard to the futuro can be accounted for by making an appeal to the former's pronounced degree of subjectivity, which has the effect of presenting a prediction as a purely conjectural evaluation. This emerges quite clearly in the contrast between predictions formulated respectively in objective (5a) and subjective terms (5b) where the Italian translation prefers the futuro in both cases, while in the German original text the Präsens contrasts with the Futur I:

(5) a. Den Efeu schneid.Prs ich, wenn du kommst.PRs, du weißt, du hast die Schlüssel immer noch. 
Taglierò.Fut l'edera quando verrai.Fut, le chiavi, lo sai, le hai ancora tu. I'll cut the ivy when you come. Remember, you still have the keys.

b. 'Wenn [der Hurrikan] kommt.PRs, wirst du dir in die Hosen scheißen.FuT, verdammt noch mal', sagt Kaspar ... 'Du wirst flennen.Fut und kreischen.FuT'.

'Quando arriverà.fut [l'uragano] ti cacherai.Fut sotto, maledizione', dice Kaspar ... 'Piangerai.Fut e strillerai.FuT'.

'If [the hurricane] does come, you'll shit in your pants, damn it all, says Kaspar ... 'You'll be wailing and blubbering.'

The stronger subjective value of the futuro compared to the Futur I is confirmed by the high number of cases - about 40 per cent in Table 2.3 - in which it translates a Präsens like the following one:

(6) Ich sah aus dem Autofenster und dachte: 'Das ist.Prs es noch fünf Minuten'. Guardai fuori dal finestrino e pensai: 'Sarà.FuT questa ma per non più di cinque minuti ancora'.

I looked out of the car window and thought, That's it for another five minutes, maybe.

Note that the subjective value is explicitly expressed in English by means of the afterthought maybe. Thus, in Italian, the dividing line between subjective and objective predictions is pulled further up towards reliability in the scale seen in Table 2.2, as shown by the following examples in which the presente and the progressive form refer respectively to a promise involving the highest personal engagement (7a) and to an event presented as imminent, although in truth it is not $(7 b)$ :

(7) a. 'Platz genug, verstehst du? Platz genug! Ich mach.PRs euch hier 'nen Salon und 'n

Billardzimmer und 'n Rucherzimmer, und jedem seinen eigenen Raum'.

'Cè posto abbastanza, capisci? Posto abbastanza! Io vi faccio.Prs un salone e una sala da biliardo e una sala per fumatori, e a ciascuno la sua camera'.

'Plenty of room, you understand? Plenty of room. I'll build you a salon here, and a billiard room, and a smoking room, and separate rooms for everyone.'

b. 'Stein' rief ich. 'Komm da raus! Es stürzt.prs zusammen!'

'Stein!' gridai. 'Vieni fuori! Sta crollando.Prog!'.

'Stein!' I called up. 'Get out of there! It's going to collapse!'

Let us now turn to the past time reference, which offers a more complex picture insofar as at least two different tenses are present in the three languages, namely a present perfect - corresponding respectively to the German Perfekt and to the Italian passato prossimo - and a simple past - corresponding respectively to the German Präteritum and to the Italian passato remoto. 
Given this complexity, it is convenient to adopt in this case a semasiological perspective, taking as a vantage point the German Perfekt, which displays a variety of different values that only partially have correspondences in the other two languages (cf. König and Gast 2007: 87-92):

(8) a. resultative (hot news)

i. Schau mal, es hat geschneit.

Look, it has snowed.

Guarda, ha nevicato.

ii. Die Maschine aus Paris ist gelandet.

The airplane from Paris has landed.

Laereo da Parigi è atterrato.

b. narrative

i. Gestern sind wir ins Kino gegangen.

Yesterday we went to the cinema.

Ieri siamo andati al cinema.

ii. Anschließend haben wir bei einem Italiener gegessen.

Then we ate at an Italian restaurant.

Poi abbiamo mangiato in un ristorante cinese.

c. future

i. Wenn du das nächste Mal kommst, sind wir schon umgezogen.

The next time you come, we'll already have relocated.

La prossima volta che vieni, avremo già traslocato.

ii. Morgen Abend habe ich dieses Kapitel abgeschlossen.

I will finish this chapter tomorrow night.

?(Entro) domani sera ho finito questo capitolo.

d. universal (non-persistent)

i. Ich habe seit mehr als zehn Jahren nicht mehr getanzt.

(Bitte entschuldigen Sie, wenn ich Ihnen auf die Füße trete.)

I have not been dancing for more than ten years. (I apologize if I step on

your foot.)

Non ballo da più di dieci anni.

ii. Ich tanze seit mehr als zehn Jahren nicht mehr.

I have not danced for more than ten years.

Non ballo da più di dieci anni.

e. existential (experiential)

i. Ich habe schon mal Tennis gespielt.

I have already played tennis.

Ho già giocato a tennis in passato.

ii. Ich bin Gerhard Schröder erst einmal begegnet.

I have met Gerhard Schröder only once.

Ho incontrato Gerhard Schröder solo una volta. 
iii. Ich bin Willy Brandt nur einmal begegnet.

I met Willy Brandt only once.

Ho incontrato Willy Brandt solo una volta.

While the resultative value ( $8 \mathrm{a})$ is expressed in the three languages by the similar construction based on HAVE + past participle, English clearly contrasts with German and Italian with regard to the narrative value because it can only use the simple past (8b) even for events placed in the recent past. On the other hand, while the German Perfekt can be used with a resultative value projected into the future (8c), this is impossible in English - as expected in the light of the previous discussion - and only possible to a limited extent in Italian, where, however - as in English - the future anteriore or future perfect is largely preferred. Furthermore, the English present perfect can be used with a so-called 'universal value', referring to a state of affairs which has been true in the past and is still persisting at the moment of utterance, as shown in (8dii), while in German and Italian, this has to be conveyed by the Präsens / presente. On the other hand, the German Perfekt can be used to refer to a non-persistent state of affairs, while in English and Italian, this has to be done by means of the present perfect progressive and of the presente. Finally, while the three languages converge in using the perfect for the so-called 'existential value' referring to personal experiences which have been made in the past (8ei), English and German can also distinguish between the possibility of repeating the experience in the future or not, by making use respectively of different tenses (present perfect and simple past) and of different adverbs (8eii-iii).

One important aspect of the contrast between the two different tenses used for referring to past events relates to the expansion - observed in German and in Italian of the Perfekt / passato prossimo towards also covering narrative values in the case of events placed in the distant past besides those seen in ( $8 \mathrm{bi}-\mathrm{ii})$ above:

(9) a. Im letzten Jahr besuchte ich China habe ich China besucht.

Lanno scorso visitai $\sim$ ho visitato la Cina.

Last year I visited China.

b. L'anno scorso visitai la Cina e vidi anche Sciangai. Lanno scorso ho visitato $\sim$ ?"visitai la Cina e ci rivado ora.

'Last year I visited China and I also saw Shanghai. / Last year I visited China and I'm going there again now'

c. Plötzlich ging das Licht aus und es wurde dunkel. / Plötzlich ist das Licht ausgegangen und es ist dunkel geworden.

Improvvisamente si spense la luce e divenne buio. / Improvvisamente si è spenta la luce ed è divenuto buio.

'Suddenly the light turned off and it became dark'

d. Deswegen ist er gekommen. Zum Hausarzt ist er nicht gegangen, weil er gestern gearbeitet hat und weil's noch nicht so schlimm war.

Therefore he has come. He didn't go to the doctor because yesterday he worked / ${ }^{\star}$ has worked / ${ }^{\star}$ has been / was working and it *has been / was not so painful.

Perciò è venuto. Non è andato dal dottore perché ieri ha lavorato / lavorava e non è stato / stava poi così male. 
e. Hat Michael Jackson noch gelebt als ihn sein Leibarzt fand?

Was / *Has been Michael Jackson still alive when his physician found him?

Era / ${ }^{*}$ È stato ancora vivo Michael Jackson quando lo trovò il suo medico?

In neat contrast with English which only admits the simple past, in (9a) the Perfekt and the passato prossimo are largely used for referring to distant past events as an alternative to the Präteritum and the passato remoto - especially in colloquial speech registers and respectively in the South and in the North of their national territories. For Central and Southern varieties of Italian, however, a further distinction has to be observed in (9b): the usage of the passato prossimo for referring to distant past events is sensitive to the topicrelevance of the event for the speech act situation. If the distant past event is topic-relevant, the passato prossimo has to be used, while a purely narrative context requires a passato remoto with an aoristic value. Furthermore, notice that in the absence of any temporal reference, the usage of the Perfekt and of the passato prossimo in (9c) remains non-specific with regard to the distance from the utterance time, while the Präteritum and the passato remoto clearly collocate the event in the distant past - and also adds a certain literary flavour. Finally, in German, the effect of the expansion of the Perfekt at the expenses of the Präteritum has further consequences on the tempo-aspectual system, insofar as the former also comes to be used in clearly imperfective contexts. In (9d), the German Perfekt corresponds to an English simple past - as expected - or to the progressive form, depending on the aspectual nuance that the speaker intends to emphasize, while in Italian - besides the expected passato prossimo - the imperfetto can be used, again depending on the intended meaning. The imperfective value is the only choice in (9e), where the German Perfekt cannot assume any possible perfective nuance. In other words, the systematic replacement of the Präteritum - which is not intrinsically specified for perfectivity by means of the Perfekt causes a breach through the perfective/imperfective wall in German, while the distinction remains robustly stable in English and Italian, thanks to the presence of clearly imperfective tenses. Note that the disappearance of the preterital tense in Southern German (also referred to as Präteritumschwund in the German-speaking literature, cf. DUDEN: 520) and in Northern Italian is particularly interesting from the viewpoint of the areal perspective advocated previously as a possible dimension relevant for Contrastive Analysis, as well as for the purposes of a micro-typology.

The following table summarizes - from an onomasiological viewpoint - the most salient distinctions outlined above, with the addition of the future perfect and of the past perfect which are used in a roughly similar way in the three languages:

Asymmetries and differences are particularly pronounced in the three Onomasiological Categories of [imperfective], [universal/persistent] and [narrative], while in the other cases - in spite of minor differences - the usage of the tenses largely overlaps in the three languages. This complex network of relations is charted in Figure 2.2, in which the semasiological correspondences of the single tenses in the three languages are shown, which are indirectly connected to each other by means of the Onomasiological Categories summarized in Table 2.4.

As can be gathered from the chart, the picture is multi-faceted, in that only in a few cases is the relationship between the two levels bidirectional or at least unidirectional. On the other hand, the Contrastive Analysis is able to show similarities and differences reaching a high degree of detail and complexity. 


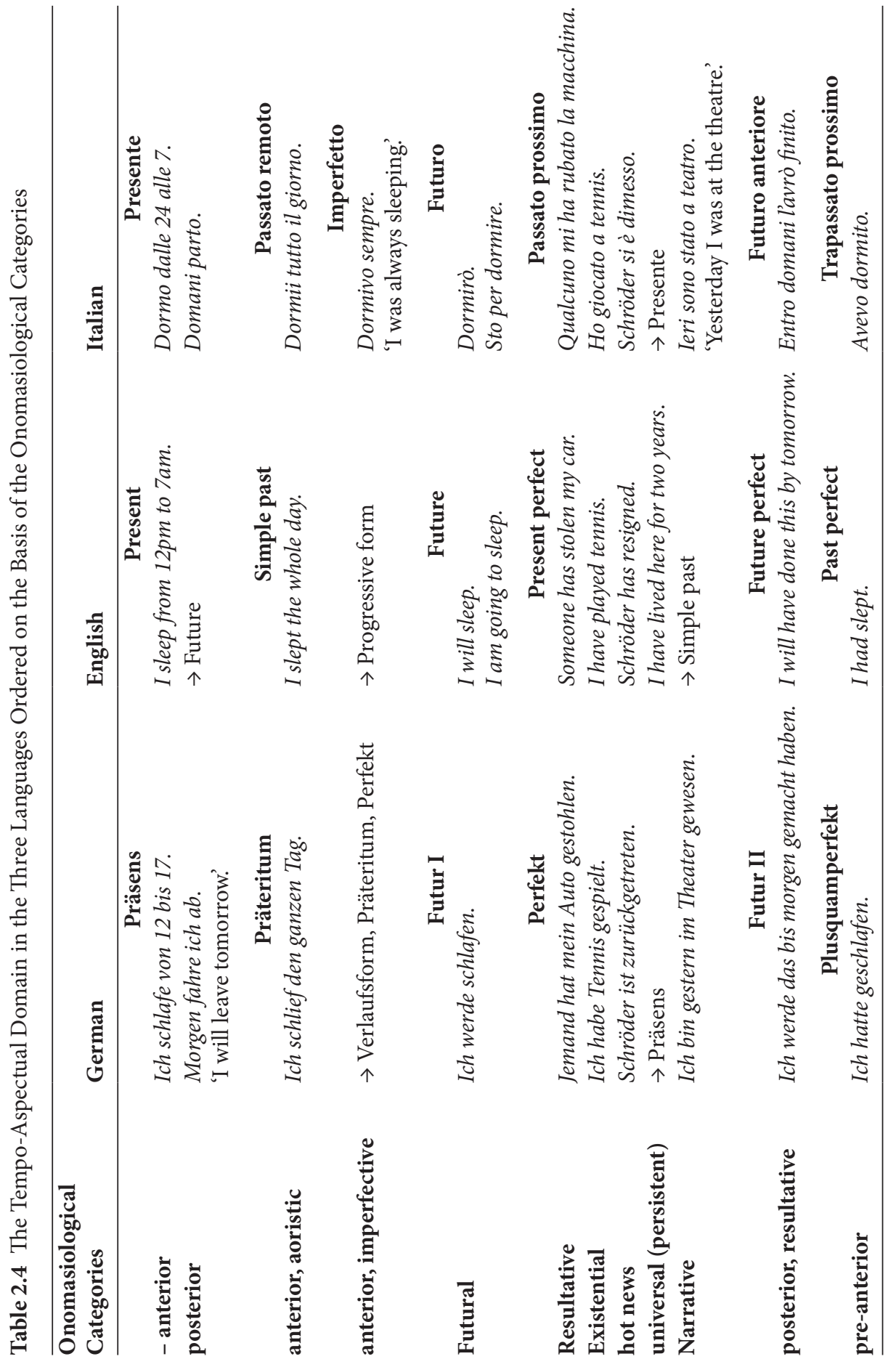




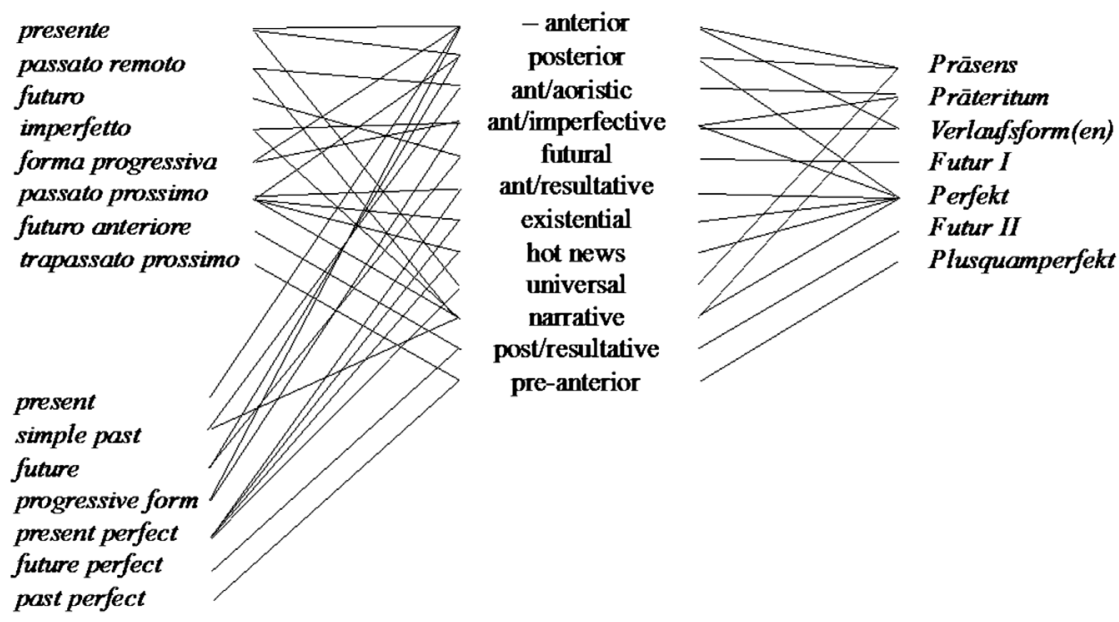

Figure 2.2 Semasiological correspondences in the three languages.

\subsection{Properties of subjects and objects}

The properties of subjects and objects refer to the morphosyntactic domain and are interesting to the extent that the relations among the three languages are quite varied. On the one hand, English and German - traditionally described as non-pro-drop languages - clearly contrast with Italian with regard to the subject properties:

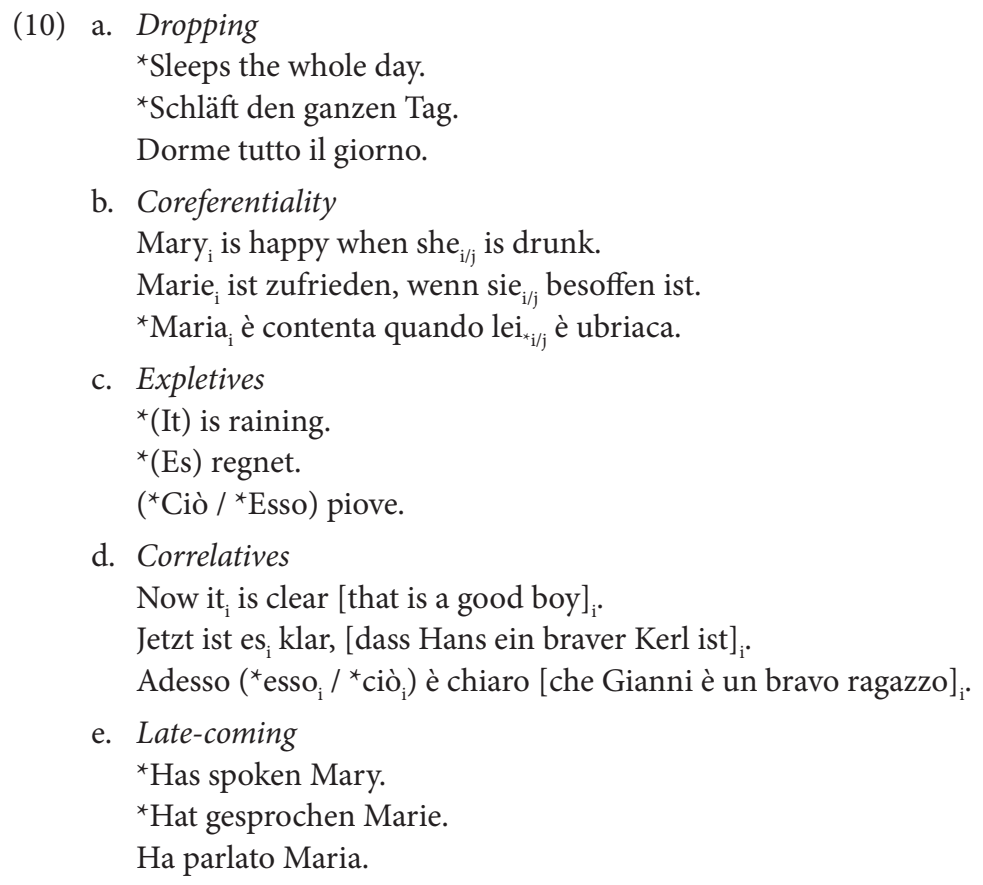


f. Dislocability of the relative sentence

A man $_{\mathrm{i}}$ came whom $\mathrm{I}$ know well.

Ein $\mathrm{Mann}_{\mathrm{i}}$ ist gerade angekommen, den ${ }_{\mathrm{i}}$ ich gut kenne.

${ }^{\star}$ Un uomo $_{i}$ è appena arrivato che ${ }_{i}$ conosco bene.

g. Extraction

${ }^{*}$ Who $_{i}$ do you think that ${ }_{-i}$ will come?

${ }^{\star}$ Wer $_{i}$ glaubst du, dass ${ }_{-i}$ kommen wird?

$\mathrm{Chi}_{\mathrm{i}}$ credi che $_{-\mathrm{i}}$ verrà?

Besides dropping (10a), English and German also converge with regard to the use of the subject pronoun for referring to the subject of the main clause (10b), of the expletives (10c) and of the correlatives (10d). Moreover, the subject cannot be freely dislocated at the end of the clause (10e), while its initial position does not require a relative clause to be immediately adjacent (10f). Finally, a subject cannot be freely extracted from a dependent clause $(10 \mathrm{~g})$, although this latter option is partially available in German in dependence on longer clauses which provide more context to justify the extraction (cf. Bayer 2005): Wer $r_{\mathrm{i}}$ glaubst du, dass -1933 Bürgermeister in Hamburg gewesen ist? (lit.: Who $_{\mathrm{i}}$ do you think that ${ }_{-\mathrm{i}}$ was the mayor in Hamburg in 1933?).

On the other hand, if we turn to the properties of the object, the picture is radically different, insofar as German goes with Italian and clearly contrasts with English. This is especially true of the object extraction from subordinate clauses embedded within an interrogative sentence (cf. König and Gast 2007: 219-21):

(11) a. [- clause-external]

[ $_{\text {+FIN }}$ Who $_{\mathrm{i}}$ has Charlie seen ${ }_{-\mathrm{i}}$ in our garden?]

[ $_{\text {+FIN }}$ Wen $_{\mathrm{i}}$ hat Karl in unserem Garten ${ }_{-\mathrm{i}}$ gesehen?]

$\left[_{+\mathrm{FIN}} \mathrm{Chi}_{\mathrm{i}}\right.$ ha visto $-\mathrm{i}$ nel nostro giardino Carlo?]

b. [+ clause-external], [- finite]

[ $_{\text {FIN }}$ Who $_{\mathrm{i}}$ did Charlie believe [-FIN $_{-\mathrm{in}}$ to see ${ }_{-\mathrm{i}}$ in the garden?]]

[+FIN $_{\text {Hen }}$ glaubte Karl [-FIN im Garten $_{-\mathrm{i}}$ zu sehen?]]

$\left[_{\text {+FIN }} \mathrm{Chi}_{\mathrm{i}}\right.$ credette $_{{ }_{-\mathrm{FIN}}}$ di vedere ${ }_{-\mathrm{i}}$ in giardino] Carlo?]

c. [+ clause-external], [+ finite]

[ $_{\text {+FIN }}$ Who $_{\mathrm{i}}$ did he believe + $_{\text {FIN }}$ that he saw ${ }_{-\mathrm{i}}$ in the garden?]]

${ }^{*}\left[_{+\mathrm{FIN}}\right.$ Wen $_{\mathrm{i}}$ glaubte Karl [ ${ }_{\text {+FI }}$ dass er im Garten ${ }_{-\mathrm{i}}$ sah?]]

${ }^{*}\left[_{+\mathrm{FIN}} \mathrm{Chi}_{\mathrm{i}}\right.$ credette $\left[_{+\mathrm{FIN}}\right.$ che vide ${ }_{-\mathrm{i}}$ in giardino] Carlo?]

d. [+ clause-external], [- finite], [- argument]

$\left[_{\text {+FIN }}\right.$ What $_{\mathrm{i}}$ did he come $\left[_{-\mathrm{FIN}}\right.$ in order to pick up ${ }_{-}$? $\left.]\right]$

${ }^{*}{ }_{\text {+FIN }}$ Was $_{\mathrm{i}}$ ist er gekommen, [- ${ }_{-\mathrm{FIN}} \mathrm{um}_{-\mathrm{i}}$ abzuholen?]]

${ }^{*}{ }_{\text {+FIN }}$ Cosa $_{\mathrm{i}}$ è venuto qui $\left[_{\text {-FIN }}\right.$ per comprare ${ }_{-1}$ ?] $]$

e. [+ clause-external], [+ finite], [- argument]

${ }^{*}\left[_{\text {+FIN }}\right.$ Which film $\mathrm{i}_{\mathrm{i}}$ did you go to the movies $\left[_{\text {+FIN }}\right.$ even though you did not want to see ${ }_{-i}$ ?] ]

$\left[_{\text {+FIN }}\right.$ You went to the movies $\left[_{\text {+FIN }}\right.$ even though you did not want to see which film?]] 
Table 2.5 Object Extraction from Dependent Clauses in the Three Languages

\begin{tabular}{lcccc}
\hline clause- & \multicolumn{4}{c}{ clause-external } \\
\cline { 2 - 5 } internal & \multicolumn{2}{c}{ argument clauses } & \multicolumn{2}{c}{ circumstantial clauses } \\
& non-finite & finite & non-finite & finite \\
\hline German / Italian & \multicolumn{3}{c}{ English } \\
\cline { 2 - 5 }
\end{tabular}

It has to be added that the crucial cut-off point of the implicational hierarchy - which is summarized in Table 2.5 below - consisting of the possibility of extracting an object from a finite dependent argument clause (11c) is partially possible in German and Italian when the object refers to inanimate referents:

(12) $\left[_{+\mathrm{FIN}}\right.$ What $_{\mathrm{i}}$ do you think + $_{\text {+FIN }}$ (that) he will say ${ }_{-}$? ?]

[+FIN Was $_{\mathrm{i}}$ denkst du, [ ${ }_{+\mathrm{FIN}}$ Was $_{\mathrm{i}} /{ }^{*}$ dass er ${ }_{-\mathrm{i}}$ sagen wird?]]

$\left[_{\text {+FIN }}\right.$ Che $_{\mathrm{i}} / \operatorname{Cosa}_{\mathrm{i}}$ pensi $\left[_{+\mathrm{FIN}}\right.$ che $/\left({ }^{*} \cos \mathrm{a}_{\mathrm{i}}\right)_{-\mathrm{i}}$ dirà? $\left.]\right]$

However, this possibility involves for German the employment of the interrogative pronoun was which is co-referent with the object of the embedded clause.

As shown by Table 2.5 German and Italian contrasts with English which is more liberal as to the possibility of object extraction, which, however, does not extend to a finite dependent circumstantial clause (11e):

Finally, this implicational hierarchy - and especially its cut-off point - also holds for the accessibility to an object extracted from a clause embedded within a relative clause, in which German and Italian contrast again with English:

(13) The $\operatorname{man}_{\mathrm{i}}\left[_{+\mathrm{FIN}}\right.$ who $_{\mathrm{i}}$ you think $\left[_{\text {+FIN }}\right.$ you saw $\left.\left.{ }_{-\mathrm{i}}\right]\right] \ldots$

${ }^{*}$ Der Mann $_{\mathrm{i}},\left[_{+\mathrm{FIN}}\right.$ welchen $_{\mathrm{i}}$ du glaubst, $\left[_{+\mathrm{FIN}}\right.$ dass du ${ }_{-\mathrm{i}}$ sahst $\left.]\right] \ldots$

${ }^{*}$ L'uomo $_{\mathrm{i}}\left[_{\text {+FIN }}\right.$ che $_{\mathrm{i}}$ pensasti $\left[_{\text {+FIN }}\right.$ che vedesti $\left.{ }_{\mathrm{i}} \mathrm{i}\right] \ldots$

In other words, the functional domain identified by Table 2.5 above emphasizes a crucial distinction relating to the blocking effect of clausal boundaries on anaphoric chains.

\section{Conclusion}

To sum up, Contrastive Analysis as a highly granular 'micro-typology' has many insights to offer, not only for typologists. In particular, English as a global language can be used as a tool in the learner's hands to detect relevant generalizations concerning the mother tongue and the second foreign language.

Italian learners of German as L3 can benefit from mastering English as L2 because of similar structural traits (often revealing similar diachronic paths), as, for instance, in the case of the pronominal subject. On the other hand, Italian and German pattern 
alike in several respects, as, for instance, with regard to object extraction across clauses which are nicely captured in contrast to English. A similar multi-faceted picture is also found for the other domains investigated here: for instance, Italian and English reveal commonalities with regard to the imperfective and imminential periphrases, while German and Italian partially share the (areal) development of the present perfect. In sum, in spite of its privileged status as a global language English is more than a mere tertium comparationis, because it is different enough from the other languages to stand alone as a peculiar system illuminating with its difference the other systems involved. Accordingly, it represents an important base on which the speakers can build their further competence in a second foreign language.

\section{Notes}

1 Parts of this chapter were presented as paper at the 8th International Contrastive Linguistics Conference (Athens, 25-28 May 2017) as well as in talks given at the University of Naples 'Federico II', Genoa and Milan. I am very grateful to the people present on these occasions for insightful questions and remarks. Needless to say, I am solely responsible for any remaining mistakes.

2 Fries (1983: 4-5) suggested developing a Theoretical Contrastive Linguistics which should be opposed - in compliance with its wider typological orientation - to Applied Theoretical Contrastive Linguistics that was to be thought of as more concerned with a didactic dimension. In this regard, however, Lotz (1968: 10) had already observed: 'The question has often been raised whether contrastive studies belong to pure linguistics or to applied linguistics. I do not see much relevancy in such a compartmentalization, but it reminds me of the saying of the famous mathematician Courant, founder of NYU's Institute for Applied Mathematics: "Pure mathematics is a small and not very significant part of applied mathematics."

3 In this regard, see also Zuanelli Sonino (1976), which is however only limited to the phonological comparison.

\section{References}

Bayer, J. (2005), 'Was beschränkt die Extraktion? Subjekt - Objekt vs Topic - Fokus', in F. J. D’Avis (ed.), Deutsche Syntax: Empirie und Theorie, 233-57, Göteborg: Acta Universitatis Gothoburgensis.

Blasco Ferrer, E. (1999), Italiano e tedesco: un confronto linguistico, Torino: Paravia.

Bosco Coletsos, S. and M. Costa (2013), Italiano e tedesco. Questioni di linguistica contrastiva, Alessandria: dell'Orso.

Carroll, M. and M. Lambert (2006), 'Reorganizing Principles of Information Structure in Advanced L2s: A Study of French and German Learners of English', in H. Byrnes, H. D. Weger-Guntharp and K. A. Sprang (eds), Educating for Advanced Language Capacities, 54-73, Georgetown, Washington D.C.: Georgetown University Press.

Crystal, D. (2003), English as a Global Language, Cambridge, UK: Cambridge University Press. 
de Groot, C. (2000), 'The Absentive', in Ö. Dahl (ed.), Tense and Aspect in the Languages of Europe, 693-719, Berlin: Mouton de Gruyter.

Di Meola, C. and D. Puato (2015), Deutsch kontrastiv aus italienischer Sicht, Frankfurt/ Main: Lang.

DUDEN = Grammatik der deutschen Gegenwartssprache (2005), 7th edn, Mannheim: Dudenverlag.

Fries, C. C. (1945), Teaching and Learning English as a Foreign Language, Ann Arbor, MI: University of Michigan Press.

Fries, N. (1983), Syntaktische und semantische Studien zum frei verwendeten Infinitiv und $z u$ verwandten Erscheinungen im Deutschen, Tübingen: Narr.

Gaeta, L. (2006), 'Il Futur tedesco tra temporalità e modalità, in L. Schena, C. Preite and S. Vecchiato (eds), Gli insegnamenti linguistici dell'area economico-giuridica in Europa. Il concetto di futurità nella codificazione linguistica. XIV Incontro del Centro Linguistico. Università Bocconi, 26 Novembre 2005, 183-201, Milano: Egea.

Gaeta, L. (2014), 'Kontrastive Linguistik nach der typologischen Wende. Kommentar zu den Beiträgen', Germanistische Mitteilungen, 40 (1): 79-82.

Gast, V. (2011), 'Contrastive Linguistics: Theories and Methods', in B. Kortmann and J. Kabatek (eds), Wörterbücher zur Sprach- und Kommunikationswissenschaft Online: Linguistic Theory and Methodology, Berlin: de Gruyter.

Gast, V. (2013), 'Contrastive Analysis', in M. Byram and A. Hu (eds), The Routledge Encyclopedia of Language Teaching and Learning, 2nd edn, 153-8, London: Routledge.

Haspelmath, M. (2001), 'The European Linguistic Area: Standard Average European', in M. Haspelmath, E. König, W. Oesterreicher and W. Raible (eds), Language Typology and Language Universals, vol. 2, 1492-510, Berlin: Mouton de Gruyter.

Haspelmath, M. (2010), 'Comparative Concepts and Descriptive Categories in Crosslinguistic Studies', Language, 86: 663-87, 696-9.

Hawkins, J. A. (1986), A Comparative Typology of English and German: Unifying the Contrasts, London: Croom Helm.

Hawkins, J. A. and L. Filipović (2011), Criterial Features in L2 English, Cambridge, UK: Cambridge University Press.

Hopper, P. and E. C. Traugott (2003), Grammaticalization, 2nd edn, Cambridge, UK: Cambridge University Press.

Hüning, M., U. Vogl and T. van der Wouden (eds), (2006), Nederlands tussen Duits en Engels, Leiden: Stichting Neerlandistiek.

Iamartino, G. (2001), 'La contrastività italiano-inglese in prospettiva storica', Rassegna Italiana di Linguistica Applicata, 33: 7-130.

König, E. (1996), 'Kontrastive Grammatik und Typologie', in E. Lang and G. Zifonun (eds), Deutsch - typologisch, 31-54, Berlin: de Gruyter.

König, E. (2012a), 'Zur Standortbestimmung der Kontrastiven Linguistik innerhalb der vergleichenden Sprachwissenschaft', in L. Gunkel and G. Zifonun (eds), Deutsch im Sprachvergleich. Grammatische Kontraste und Konvergenzen, 13-40, Berlin: de Gruyter.

König, E. (2012b), 'Contrastive Linguistics and Language Comparison', Languages in Contrast, 12: 3-26.

König, E. and V. Gast (2007), Understanding English-German Contrasts, 3rd edn, Berlin: Schmidt.

Kufner, H. L. (1962), The Grammatical Structures of English and German, Chicago, IL: Chicago University Press.

Lado, R. (1957), Linguistics across Cultures: Applied Linguistics for Language Teachers, Ann Arbor, MI: University of Michigan Press. 
Langacker, R. (1991), Concept, Image, Symbol: The Cognitive Basis of Grammar, Berlin: Mouton de Gruyter.

Lotz, J. (1968), 'Introductory Remarks', in J. E. Alatis (ed.), Report of the 19th Annual Round Table Meeting: Contrastive Linguistics and its Pedagogical Implications, 9-10, Washington DC: Georgetown University Press.

Moulton, W. (1962), The Sounds of English and German, Chicago, IL: University of Chicago Press.

Nabokov, V. (1953/1989) Pnin, New York: Vintage International.

Ramat, P. (1998), 'Typological Comparison and Linguistic Areas: Some Introductory

Remarks', Language Sciences, 20: 227-40.

van der Auwera, J. (2012), 'From Contrastive Linguistics to Linguistic Typology',

Languages in Contrast, 12: 69-86.

Vanni, A. M. (2016), Quaderno di grammatica inglese. Elementi di linguistica contrastiva, Palermo: Leima.

von Stutterheim, Ch. and M. Lambert (2005), 'Cross-linguistic Analysis of Temporal Perspectives in Text Production', in H. Hendricks (ed.), The Structure of Learner Varieties, 203-31, Berlin: Mouton de Gruyter.

Zuanelli Sonino, E. (1976), Italiano, tedesco, inglese: analisi contrastiva a livello fonico, Bergamo: Minerva Italica. 